\title{
PERAN TRILOGI SYAREKAT ISLAM DALAM MEWUJUDKAN PENDIDIKAN YANG BERMARTABAT DAN MODERN
}

\author{
Oleh: \\ Triwahyu Budiutomo \\ Universitas Cokroaminoto Yogyakarta
}

\begin{abstract}
Abstrak
Pendidikan merupakan sebuah indikator penting untuk mengukur kemajuan sebuah bangsa. Jika sebuah bangsa ingin ditempatkan pada pergaulan dunia dalam tataran yang bermartabat dan modern, maka yang pertama-tama harus dilakukan adalah mengembangkan pendidikan yang memiliki relevansi dan daya saing bagi seluruh anak bangsa. Trilogi Syarekat Islam : Sebersih-bersih Tauhid, Setinggi-tinggi ilmu dan Sepandai-pandai siasah sangat tepat untuk dijadikan instrument dan aspirasi penegakan pendidikan yang bermartabat dan modern khususnya bagi sekolah-sekolah yang bernaung/memiliki ideology Syarekat Islam. Kemajuan Syarekat Islam terutama berkaitan dengan keberadaan lembaga-lembaga Pendidikan, hubungan tataran aspiratif dengan mengktualisasikan. Trilogi Sarekat Islam merupakan langkah yang bijaksana dan tepat. Perlu disusun kurikulum, silabus dan bahan ajar Ke-SI-an dengan fokus membentuk karakter umat untuk berkehidupan bermasyarakat, berbangsa dan bernegara yang islami , harmonis moderat dan modern.
\end{abstract}

Kata Kunci: Trilogi Syarikat Islam, Pendidikan, Martabat dan Modern

\section{Pendahuluan}

Dalam perspektif politik pendidikan, seorang filosof yunani abad pertengahan mengatakan bahwa penaklukan dunia ditentukan oleh seberapa jauh pendidikan suatu bangsa dapat dicapai dan seberapa maju bangsa-bangsa bersangkutan menguasai ilmu pengetahuan, ini berarti sebagai symbol kemajuan peradaban bangsa, penguasaan ilmu pengetahuan menjadi sangat penting, bahkan Geertz menganggap penguasaan ilmu pengetahuan sebagai bentuk ekspresi kemajuan berpikir dan berperilaku sebuah bangsa. Sebagai bagian tidak terpisah dari sistem kehidupan masyarakat, pembangunan pendidikan sekaligus juga menjadi indikator penting dari proses pembangunan karakter bangsa.

Suyanto ( 2008 : 28 ) menyatakan bahwa pendidikan kita saat ini sedang menghadapi persoalan yang amat pelik, berbagai fenomena kehidupan mencerminkan adanya gejala semakin merosotnya moralitas dalam praktik bermasyaraka, berbangsa dan bernegara. Dari berita 
diberbagai media cetak maupun elektronika, betapa mudahnya anggota masyarakat kita saat ini, tanpa rasa menyesal, berani melakukan perbuatan-perbuatan yang melanggar kaidah moral. Keadaan ini tentunya sangat ironis ketika kita melihat berbagai sumber nilai moralitas yang dalam tataran formal telah disepakati menjadi landasan kehidupan berbangsa dan bernegar seperti : Pancasila, UUD 1945 dan berbagai peraturan perundangan yng seharusnya menjadi sumber dan pengendali tegaknya nilai-nilai moral bermasyarakat, berbangsa dan bernegara Nilai-nilai luhur universal yang terkandung dalam Pancasila, beserta berbagai landasan hukum yang kita miliki ternyata belum efektif mengkondisikan bangsa kita yang memiliki praktik hidup bermasyarakat secara santun dan bermartabat. Lembaga pendidikan Syarekat Islam yng lebih dikenal dengan sebagai Lembaga pendidikan Cokroaminoto merasa bertanggungjawab untuk ikut serta memperbaiki pendidikn bangsa. Pada dekade menyongsong kemerdekaan Republik Indonesia tahun 1945, Syarekat Islam dengan Triloginya telah membuktikan berhasil menjawab tantangan jaman saat itu, dari perjuangan bahkan berhasil mencetak pemimpin-pemimpin bangsa, salah satunya adalah Soekarno (presiden RI yang pertama). Trilogi Sarekat Islam : (1) Sebersih-bersih Tauhid, (2) Setinggi-tinggi ilmu dan (3) Sepandai-pandai siasah. Pertanyaan kita tentunya, bisakah Trilogi Syarekat Islam digunakan sebagai instrumen /aspirasi bagi upaya penegakan pendidikan yang bermartabat dan modern ? dan bagaimanakah langkah-langkah kongkrit penerapan Trilogi Syarekat Islam pada pelaksanakan pendidikan yang bermartabat dan modern serta sebagai upaya mewujudkan kehidupan bermasyarakat, berbangsa dan bernegara yang harmonis.

\section{Syarekat Islam}

Syarekat Islam mempunyai cita-cita untuk menegakkan Islam secara utuh sehingga terealisasikan syarikat Islam yang sedalam dan seluas-luasnya. Strategi pencapaian ini didasarkan pada tiga prinsip utama, yaitu : (1) Sebersih-bersihnya Tauhid; (2) Setinggi-tingginya ilmu dan Sepandai-pandainya siasah.

\section{Sebersih-bersihnya Tauhid}

Dalam segala sikap dan perilaku kita tidak mensekutuhan Tuhan kecuali Allah swt. Artinya, manusia syarekat Islam adalah manusia yang selalu menyadari diri bahwa semua yang dilakukan adalah ibadah atau pengabdian kepada Allah swt. Secara material maupun psikologis 
sikap perilaku ini akan selalu membuat rasa tenang danjh percaya diri dalam setiap perbuatan yang dilakukan, karena apa yang dilakukan dalam rangka ber " amal mahruf nahi munkar ".

\section{Setinggi-tingginya ilmu.}

Dalam pandangan syarikat Islam, menuntut ilmu adalah wajib. Inti dari asas ini adalah bahwa pendidikan Syarikat Islam memberikan keseimbangan pengajaran yang meliputi duniawi dan ilmu agama serta menitikberatkan pada pendidikan yang meningkatkan derajad kemanusiaan, Pendidikan syarekat Islam menekankan pada pembinaan karakter bangsa., melalui pendidikan y7ang berlandaskan trilogy Syarekat Islam diharapkan dapat memperluas wawasan dan meningkatkan ilmu yang memperkuat sebersih-bersihnya Tauhid. Semakin tinggi ilmu yang dimiliki seseorang makin kuat ke-Tauhid-an orang tersebut. Ilmu yang didapatkannya tidaklah hanya untuk memperluas wawasan diri sendiri tetapi untuk diamalkan demi kepentingan masyarakat, bangsa dan negara.

\section{Sepandai-pandai siasah.}

Sejak perintisannya Syarikat Islam tidak terlepas dari perjuangan berbangsa dan bernegara, kalau pada jaman sebelum kemerdekaan, Syarikat Islam memperjuangkan tercapainya kemerdekaan. Setelah kemerdekaan adalah mengisi kemerdekaan menuju tercapainya cita-cita bangsa dan negara adil makmur, aman dan sejahtera. Oleh karena itu, ilmu yang dikembangkan adalah ilmu yang memperkuat ke-Tauhid-an dalam upaya mewujudkan cita-cita perjuangan kemerdekaan yaitu tercapainya cita-cita kemerdekaan. Sebagaimana yang telah dilakukan para pendahulu dalam menyelesaikan berbagai permasalahan, maka dalam menyelesaikan berbagai permasalahan yang timbul saat ini harus juga dilakukan melalui siasah sesuai dengan situasi yang berkembang tetapi dengan tidak mengorbankan sikap sebersih-bersihnya Tauhid.

Ketiga prinsip utama Syarikat Islam adalah merupakan suatu kesatuan dalam arti tidak dapat dipisah-pisahkan. Sebersih-bersih Tauhid merupakan landasan semua pemikiran, sikap maupun perilaku manusia. Peningkatan ilmu merupakan upaya memperkuat Tauhid seseorang serta dalam menerapkan ilmu sebagai sebuah solusi keajiban manusia sebuah pencapaian citacita yang harus dilakukan melalui siasah yang tetap mendasarkan pada sebersih-bersihnya Tauhid, karena kesemuanya itu untuk meniungkatkan ke-Tauhid-annya.

Trilogi Syarekat Islam sangat tepat diterapkan untuk mengatasi permasalahan merosotnya moral dan martabat serta menurunnya kehidupan bermasyarakat , berbangsa dan bernegara . denganh menerapkan ketiga prinsip utama tersebut diharapkan lembaga pendidikan 
khususnya yang beraspirasi Syarekat Islam akan mencetak Sumberdaya Manusia yang bersih Tauhidnya, tinggi ilmu dan pandai dalam menerapkan ilmu untuk kehidupan bermasyarakat, berbangsa dan berbegara yang lebih baik.

Kurikulum adalah merupakan instrumen utama pendidikan. Penyusunan kurikulum Kesyarikat Islaman yang mentikberatkan pada peningkatan harkat dan martabat manusia dalam

kehidupan bermasyarakat, berbangsa dan bernegara merupakan langkah yang tepat. Melalui kurikulum yang baik selanjutnya disusun silabus dan bahan ajar ke-SI-an yang bermartabat, moderat dan terbuka merupakan langkah yng tepat

\section{Penutup}

1. Trilogi Syarekat Islam : Sebersih-bersih Tauhid, Setinggi-tinggi ilmu dan Sepandai-pandai siasah sangat tepat untuk dijadikan instrument dan aspirasi penegakan pendidikan yang bermartabat dan modern khususnya bagi sekolah-sekolah yang bernaung/memiliki ideology Syarekat Islam.

2. Kemajuan Syarekat Islam terutama berkaitan dengan keberadaan lembaga-lembaga Pendidikan, hubungan tataran aspiratif dengan mengktualisasikan Trilogi Sarekat Islam merupakan langkah yang bijaksana dan tepat

3. Perlu disusun kurikulum, silabus dan bahan ajar Ke-SI-an dengan fokus membentuk karakter umat untuk berkehidupan bermasyarakat, berbangsa dan bernegara yang islami , harmonis moderat dan modern

\section{Daftar Pustaka}

Djaja Saefullah, 2001, Syarekat Islam Pengembangan Pendid8kan Tinggi Islam Masa Depan, Kerta Kerja, UCY, Yogyakarta.

Suyanto , 2008, Dialog Interaktif, Multi Pressindo, Yogyakarta

Pendidikan Bermrtabat, Analisis KR 2007

Pendididkan dan Moralitas, Analisis KR 2007 